\title{
SOIL MICROBIAL COMMUNITIES AND ENZYME ACTIVITY FOR DIFFERENT RECLAMATION (ECOLOGICAL RESTORATION) PATTERNS OF ABANDONED FARMLANDS IN SHIHEZI, XINJIANG, CHINA
}

\author{
PANG, W. - ZHANG, F. H. \\ College of Agriculture, Shihezi University, Shihezi, Xinjiang 832000, China \\ *Corresponding author \\ e-mail:zfh2000@126.com
}

(Received $21^{\text {st }}$ Nov 2018; accepted $25^{\text {th }}$ Jan 2019)

\begin{abstract}
Although there have been obvious land use changes in Xinjiang, China, the effect of reclamation (ecological restoration) of abandoned farmlands on soil microbial properties is rarely reported. Natural restoration of abandoned farmland was used as a control treatment, and the effects of different reclamation (ecological restoration) patterns on soil microbial properties in Shihezi, Xinjiang, China were analyzed. The results showed that there was a significant difference between different reclamation (ecological restoration) patterns in soil chemical and microbial characteristics $(P<0.05)$. These results indicate that the highest values for soil organic matter and available $\mathrm{P}$ were in accordance with the highest values for soil microbial communities (fungi, bacteria and total microbial amount), and the higher the value of $\mathrm{pH}$, the lower the activity of urease and soil microbial biomass carbon. Land use patterns, both ecological restoration and reclamation types, were useful when only soil quality improvement was considered. Because of the advantages of improvement in soil fertility, the agroforestry pattern could be used as the preferred reclamation pattern for abandoned farmland in salinized regions. By increasing the soil water content and promoting the establishment of vegetation, the water recharge pattern could be a good choice during the early stage of ecological restoration of abandoned farmland.
\end{abstract}

Keywords: Manas river basin, agroforestry pattern, soil biochemical properties, principal component analysis, land use change, arid regions, salinization

Abbreviations: RRAF: reclamation (ecological restoration) of abandoned farmlands, MES: Medicago sp., CIS: Citrullus lanatus spp., AGF: agroforestry, SWR: soil water recharge, ENP: enrichment planting, ACS: Achnatherum splendens, NAR: natural restoration of abandoned farmlands, SOC: soil organic carbon, SOM: soil organic matter, SAN: soil available N (alkali-hydrolyzable N), SAP: soil available P, MBC: microbial biomass $\mathrm{C}, \mathrm{MBN}$ : microbial biomass $\mathrm{N}$, URE: urease activity, SUC: sucrase activity, PHO: phosphatase activity, CAT: catalase activity, BAC: bacteria, FUN: fungi, ACT: actinomycetes, TMA: total microbial amount

\section{Introduction}

RRAF in arid regions is critical to ensure both sustainable development of agriculture and environmental protection (Suding, 2011; Yang et al., 2016; Zhou et al., 2017). The land use changes caused by RRAF are one of the most important reasons for global environmental changes (GLP, 2005).

Artificial measures involving fertilization, irrigation and ploughing in the process of RRAF will change plant types, which eventually leads to changes in the biochemical properties of the soil (Li et al., 2013; Liu et al., 2013; Nadimi-Goki et al., 2017). Soil biochemical properties include its microbial communities and soil enzyme activity (Bastida et al., 2008; Stott et al., 2010). Soil microbial communities are an important part of soil microbial processes, which play a critical role in nutrient 
transformation, soil health and sustaining the productivity of soil (Nannipieri et al., 2003). Soil enzyme activity is the basis for ensuring soil microbial quantity and soil physicochemical properties, and has a close relationship with the carbon and nitrogen cycle in soil (Mersi and Schinner, 1991). Moreover, soil enzyme activity can reflect the effects of plant type and crop rotation, as well as that of organic and inorganic fertilizers, etc., on soil quality (Bastida et al., 2012; Singh and Ghoshal, 2013). Soil biochemical properties are more sensitive to environmental stress than other physicochemical characteristics, which often reflect changes in soil quality, and can therefore be used to monitor soil biological processes in different land use patterns (Patra et al., 2005; Xue et al., 2008; Nadimi-Goki et al., 2017).

Unsustainable agricultural practices have resulted in the degradation and desertification of many arid ecosystems around the world (Castellanos et al., 2005), which has led to abandoned farmlands becoming a major issue worldwide (Bonet, 2004). However, there is a generalized lack of research about RRAF in arid environments (Romo-Leon et al., 2016).

In particular, inadequate use and overuse of land has contributed to serious environmental problems of land degradation in Xinjiang, northwest China (UN General Assembly, 1997). In the 50 years from 1949 to 2000, land use changes in Xinjiang were huge, indicating both abandoned farmlands caused by secondary salinization, and large-scale land reclamation caused by social and economic development (Luo et al., 2003; Fan et al., 2008; Feng et al., 2011). Land use change in the Manas river basin was especially typical in Xinjiang: the population increased from 59,000 in 1949 to 1,109,000 in 2004 ( $\mathrm{Li}$ et al., 2008), which made it become the largest artificial oasis in Xinjiang and the fourth-largest irrigated agricultural land area in China (Feng et al., 2011). With the widespread application of drip irrigation technology since 1996, large areas of abandoned farmlands have been reclaimed, and the reclamation area exceeded the abandonment area in 1999 (Qian et al., 2006).

However, the soil physical and chemical properties, vegetation composition, history of abandonment, climatic features and the plant types of reclamation (restoration) varied with the changes to abandoned farmlands; the effects of RRAF patterns on soil biochemical properties changed in different regions, and there were even some opposing conclusions. Some researches have reported that soil microbial communities and enzyme activity increases after land reclamation (ecological restoration) (Tan and Kang, 2009; Liu et al., 2013; Guo et al., 2014). Nevertheless, other studies have found that the decline in soil organic $\mathrm{C}$ results in a decrease in soil bacteria, fungi and actinomycetes (Yin et al., 2013), the catabolic diversity of soil microbial communities (Degens et al., 2000) and urease activity (Raiesi and Beheshti, 2014) after RRAF.

For the Manas river basin, RRAF generally involves planting of economic crops, such as Medicago sp. and Citrullus lanatus spp., and agroforestry, etc., and RRAF generally includes water recharge, enrichment planting (native plants with resistance to salt and drought stress) or planting Achnatherum splendens, etc. For the Manas river basin which has drought stress and severe secondary salinization of soil, however, little is known about the effects of RRAF on soil microbial communities and enzyme activity, and which reclamation (ecological restoration) pattern is suitable for this basin.

Based on extensive investigation among existing RRAF patterns in the Manas river basin, six representative RRAF patterns were set in Shihezi, Xinjiang. The objectives 
of this paper were to: (1) compare the differences in chemical properties, microbial communities and enzyme activity of soil among different RRAF patterns; and (2) analyze correlations between microbial communities, enzyme activity and chemical properties. We expected to provide references for RRAF in drought and salinized regions.

\section{Materials and methods}

\section{Experimental set-up and environmental conditions}

The sample plot was located in Shihezi, Xinjiang, northwest China $\left(85^{\circ} 35.275^{\prime} \mathrm{E} \sim\right.$ $85^{\circ} 38.634^{\prime} \mathrm{E}, 44^{\circ} 32.493^{\prime} \mathrm{N} \sim 44^{\circ} 33.989^{\prime} \mathrm{N}$, Fig. 1). Halosols are the dominant soils in plot. The plot is situated in the Manas river basin and has a temperate continental climate. Meteorological factors such as temperature, relative humidity, sunshine, precipitation and soil chemical properties are shown in Table 1. Six RRAF patterns, namely, planting MES and CIS, AGF, SWR, ENP and planting ACS were selected for the sample plot in 2008. According to the difference in ecosystem functions after reclamation (ecological restoration), the six RRAF patterns were classified into reclamation types including MES, CIS and AGF, and ecological restoration types including SWR, ENP and ACS. NAR was set as a control (Fig. 2). AGF consisted of tree (Populus russkii Jabl.) - wheat intercropping. SWR plots were irrigated once with $225 \mathrm{~m}^{3} / \mathrm{hm}^{2}$ in spring and autumn, respectively. ENP was set via enrichment planting of native plants, such as Reaumuria soongorica (Pall.) Maxim, Suaeda salsa L., etc., with a height of $10-15 \mathrm{~cm}$ and density of 20,000 individuals $/ \mathrm{hm}^{2}$. The seedling density of $A$. splendens was 3,000 individuals $/ \mathrm{hm}^{2}$ in ACS.

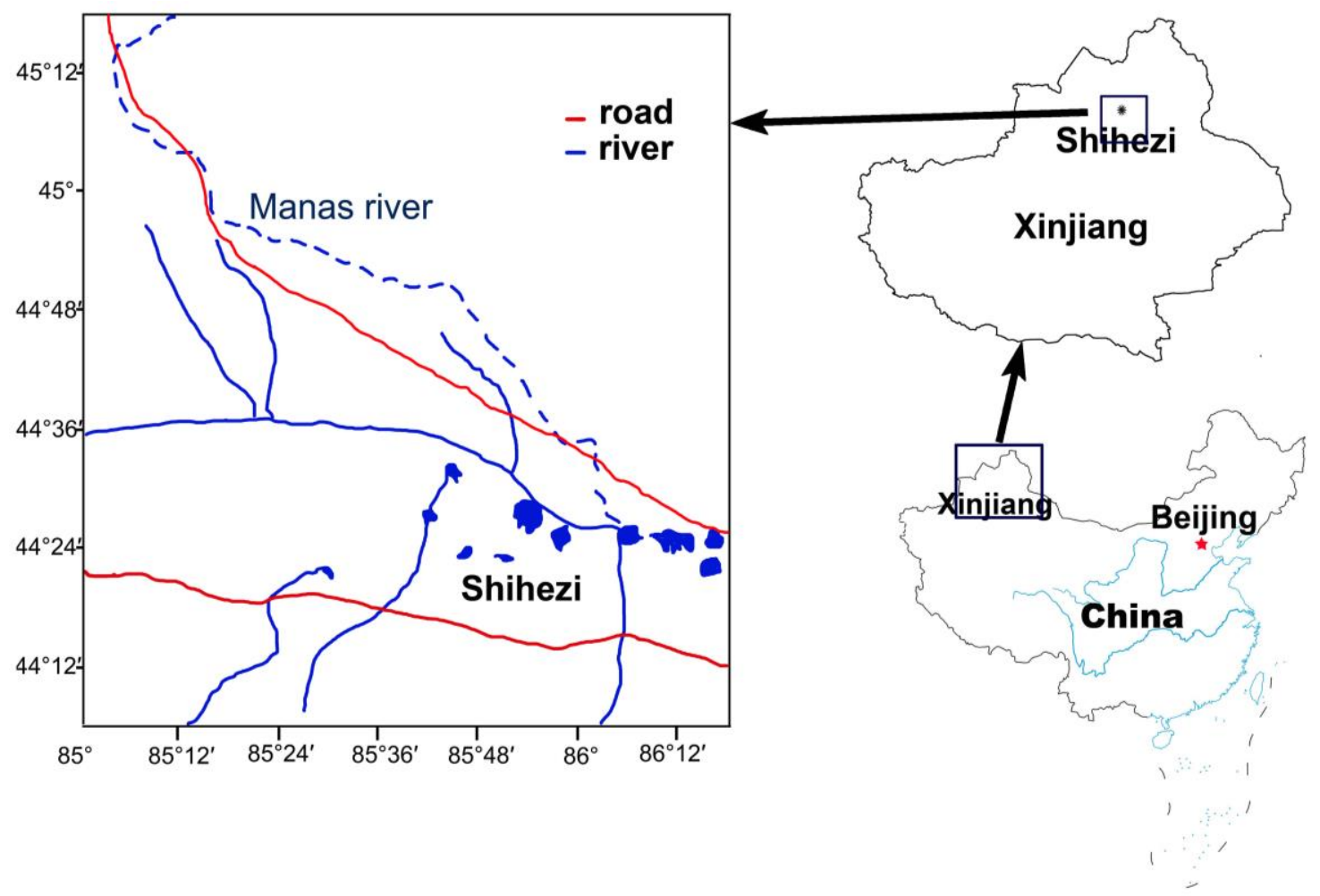

Figure 1. Sample plot in Shihezi of Xinjiang, China 

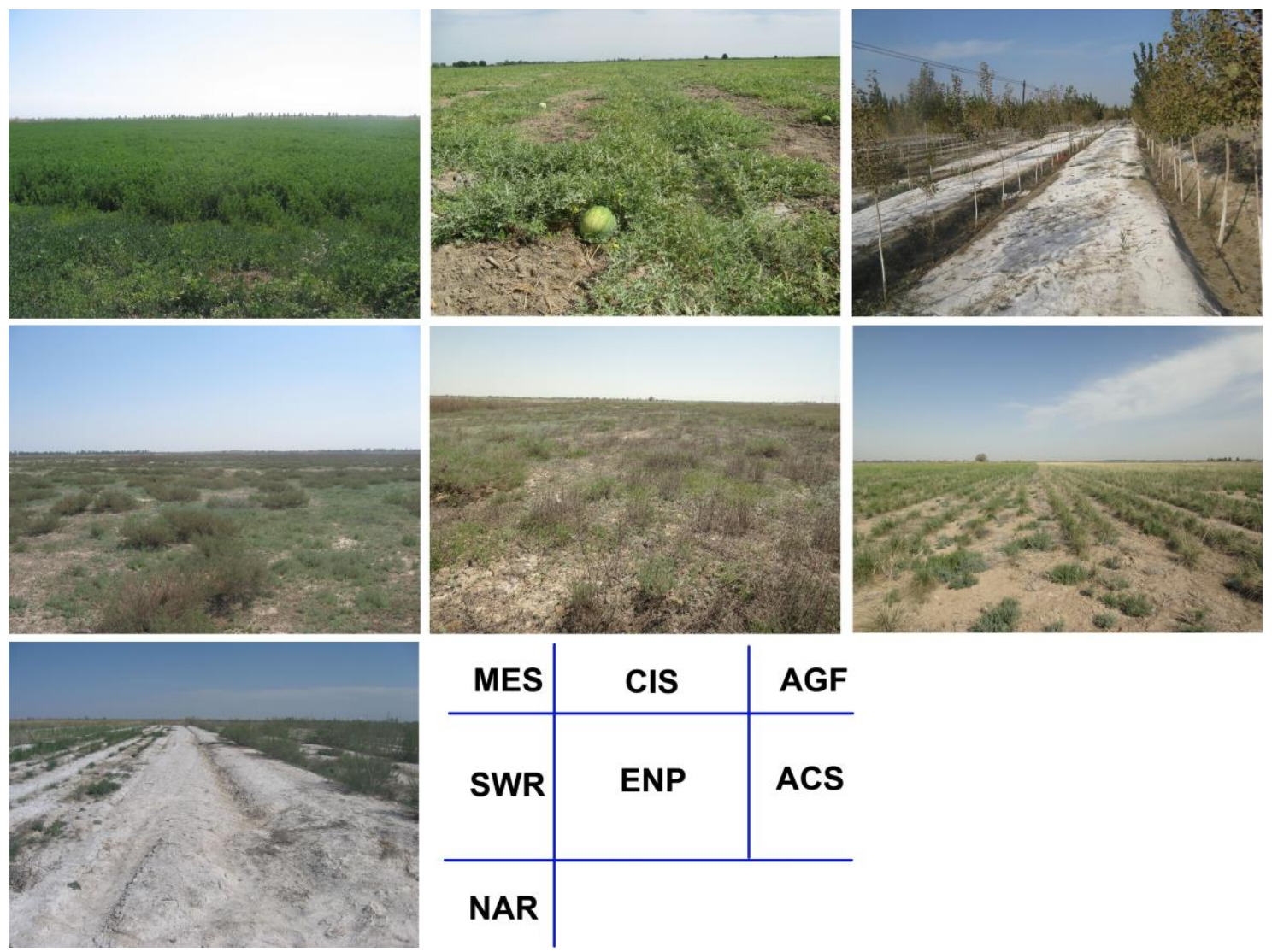

Figure 2. Six reclamation (ecological restoration) patterns of abandoned farmlands and natural restoration

Table 1. Average measured parameters (vegetation and soil) of different reclamation (ecological restoration) patterns in Shihezi of Xinjiang

\begin{tabular}{|c|c|c|c|c|c|c|c|c|}
\hline \multirow{2}{*}{\multicolumn{2}{|c|}{$\begin{array}{c}\text { Type } \\
\text { Pattern }\end{array}$}} & \multirow{2}{*}{ Control } & \multicolumn{3}{|c|}{ Reclamation } & \multicolumn{3}{|c|}{ Ecological restoration } \\
\hline & & & MES & CIS & AGF & SWR & ENP & ACS \\
\hline \multicolumn{2}{|r|}{ Climate } & \multicolumn{7}{|c|}{$\begin{array}{l}\text { Arid, continental climate with annual temperature of } 8.09^{\circ} \mathrm{C} \text {, annual relative humidity of } 63.55 \% \text {, sunlight of } \\
\qquad 2769.4 \mathrm{~h} \text { and annual precipitation of } 225.3 \mathrm{~mm}\end{array}$} \\
\hline \multirow{3}{*}{\multicolumn{2}{|c|}{$\begin{array}{l}\text { Salt content in soil } \\
\text { profile }(\mathrm{g} / \mathrm{kg})\end{array}$}} & $0-20 \mathrm{~cm}$ & \multicolumn{6}{|c|}{\begin{tabular}{|c|} 
\\
\end{tabular} $.35(1.14-17.15)$} \\
\hline & & $20-40 \mathrm{~cm}$ & \multicolumn{6}{|c|}{$3.55(1.4-11.75)$} \\
\hline & & $40-60 \mathrm{~cm}$ & \multicolumn{6}{|c|}{$3.05(1.16-9.63)$} \\
\hline \multicolumn{2}{|r|}{ Vegetation } & \multicolumn{7}{|c|}{$\begin{array}{c}\text { The dominant species are Kalidium foliatum (Pall.) Moq., Tamarix ramosissima Ledeb, Salsola collina Pall., } \\
\text { Halostachys belangeriana (H. caspica (Bieb.) C. A. Mey., Limonium spp., Karelinia caspica (Pall.) Less., } \\
\text { Melilotus officinalis (Linn.) Pall, Aristida adscensionis Linn., etc. }\end{array}$} \\
\hline \multirow{5}{*}{ Soil } & $\mathrm{pH}$ & $8.61 \pm 0.11 \mathrm{a}$ & $8.04 \pm 0.14 \mathrm{~b}$ & $8.29 \pm 0.10 \mathrm{ab}$ & $8.05 \pm 0.09 \mathrm{~b}$ & $8.32 \pm 0.17 \mathrm{ab}$ & $8.36 \pm 0.11 \mathrm{ab}$ & $7.97 \pm 0.11 \mathrm{~b}$ \\
\hline & $\mathrm{EC}(\mathrm{ms} / \mathrm{cm})$ & $5.27 \pm 0.11 \mathrm{a}$ & $2.85 \pm 0.09 \mathrm{~d}$ & $1.89 \pm 0.09 \mathrm{e}$ & $2.60 \pm 0.15 \mathrm{~d}$ & $3.66 \pm 0.07 \mathrm{c}$ & $4.27 \pm 0.10 \mathrm{~b}$ & $2.68 \pm 0.08 \mathrm{~d}$ \\
\hline & $\operatorname{SOM}(\mathrm{g} / \mathrm{kg})$ & $3.26 \pm 0.14 \mathrm{~d}$ & $6.19 \pm 0.03 \mathrm{c}$ & $6.95 \pm 0.10 \mathrm{~b}$ & $10.54 \pm 0.20 \mathrm{a}$ & $6.14 \pm 0.13 \mathrm{c}$ & $6.03 \pm 0.14 \mathrm{c}$ & $6.23 \pm 0.09 \mathrm{c}$ \\
\hline & SAN $(\mathrm{mg} / \mathrm{kg})$ & $28.19 \pm 0.68 \mathrm{~d}$ & $41.51 \pm 1.18 \mathrm{c}$ & $51.38 \pm 1.36 \mathrm{a}$ & $54.04 \pm 1.75 \mathrm{a}$ & $38.50 \pm 0.58 \mathrm{c}$ & $41.86 \pm 1.15 \mathrm{c}$ & $47.95 \pm 0.61 \mathrm{~b}$ \\
\hline & $\mathrm{SAP}(\mathrm{mg} / \mathrm{kg})$ & $5.52 \pm 0.13 \mathrm{e}$ & $7.58 \pm 0.21 \mathrm{c}$ & $8.59 \pm 0.20 \mathrm{~b}$ & $9.32 \pm 0.25 \mathrm{a}$ & $6.35 \pm 0.14 \mathrm{~d}$ & $6.03 \pm 0.19 \mathrm{de}$ & $6.44 \pm 0.13 \mathrm{~d}$ \\
\hline \multicolumn{2}{|r|}{ Irrigation } & 1 & Drip irrigation & Drip irrigation & Drip irrigation & Drip irrigation & Drip irrigation & Drip irrigation \\
\hline \multicolumn{2}{|c|}{$\begin{array}{l}\text { Fertilizer amount } \\
\quad\left(\text { per } \mathrm{hm}^{2}\right)\end{array}$} & I & $300 \mathrm{~kg} \mathrm{~N}$ & $300 \mathrm{~kg} \mathrm{~N}$ & $\begin{array}{c}300 \mathrm{~kg} \mathrm{~N}, 120 \\
\mathrm{~kg} \mathrm{P}_{2} \mathrm{O}_{5} \text { and } 60 \\
\mathrm{~kg} \mathrm{~K}_{2} \mathrm{O} \\
\end{array}$ & l & I & I \\
\hline \multicolumn{2}{|r|}{ Area $\left(\mathrm{hm}^{2}\right)$} & 2.0 & 5.0 & 5.0 & \begin{tabular}{|l|}
50.0 \\
\end{tabular} & 4.0 & 4.0 & 10.0 \\
\hline
\end{tabular}

Data are expressed as mean $\pm \mathrm{SE}$, different letters indicate a significant difference among different patterns at $P<0.05$ level. Meteorological data are collected from China Meteorological Data Network (http://data.cma.cn/) 
Soil samples were taken in an S-shaped pattern $(0-20 \mathrm{~cm})$ from five points in each plot in 2011. The five soil samples were mixed, and $1 \mathrm{~kg}$ subsamples were extracted for analysis using the quartering method (Rasapoor et al., 2009). Three subsamples within each RRAF pattern were collected, totaling 21 subsamples.

\section{Measurement of soil chemical properties, soil microbial communities and enzyme activity}

Soil chemical properties were measured from air-dried soil samples, and soil microbial communities and enzyme activity were measured from fresh soil samples. Soil $\mathrm{pH}$ was measured using an Ampholine (LKB Producter AB, Stockholm, Sweden) $\mathrm{pH}$ meter (3310, water-to-soil ratio 2.5:1). Soil EC was determined using the electrical conductivity method (DDSJ-308A conductivity meter, water-to-soil ratio5:1, dS $/ \mathrm{m}$ ). SOC was measured by the potassium dichromate oxidation method (Vance et al., 1987). SOM was calculated according to Equation 1:

$$
\mathrm{SOM}=\mathrm{SOC}(\%) / 58 \%
$$

SAN was measured using the alkaline solution diffusion method. SAP was analyzed colorimetrically using the ascorbic acid molybdate method.

Fresh soil samples were gently sieved through a $2 \mathrm{~mm}$ sieve and used for determining soil biological parameters. The soil microbial population (BAC, ACT, FUN and TMA) was measured by dilution plating, as described by Bulluck et al. (2002). Soil MBC and soil MBN were measured using the chloroform fumigation extraction method (Brookes et al., 1985; Vance et al., 1987). URE was measured using the indophenol blue method (Keeney and Nelson, 1982). SUC was determined using 3,5-dinitrosalicylic acid colorimetry. PHO was determined with the phenylene-disodium phosphoric acid colorimetric method (Guan, 1986). CAT was measured using the potassium permanganate titration method (Zhou et al., 2011).

\section{Statistical analysis}

All data were analyzed using SPSS 15.0 software (SPSS Inc., USA). Differences in soil variables between different RRAF methods were analyzed using a Duncan test in one-way ANOVA for multiple comparisons. Correlation analyses were carried out using Pearson two-tailed tests between the mean value by pattern of the soil chemical variables and the soil microbial properties, and between each of the soil microbial properties. The significance of the explained variation was analyzed using a generalized linear model (GLM, type III sum of squares, McCullagh and Nelder, 1989) according to Equation 2:

$$
Y=\mu+T+P(T)+\varepsilon
$$

In Equation 2, $Y$ is the response variable, $\mu$ is the general mean, $T$ is the effect of the type, $P(T)$ is the effect of the pattern (within a type) and $\varepsilon$ is the error term.

Soil microbial communities and enzyme activity were anaSlyzed using principal component analysis (PCA). The scatter plot was drawn using the scores of principal components. According to the scatter plot, combinations of soil microbial communities and enzyme activity between different RRAF patterns were analyzed. 


\section{Results}

\section{Soil chemical properties for different RRAF patterns}

There were significant differences between soil chemical properties for different RRAF patterns $(P<0.05$, Table 1$)$. The values of soil $\mathrm{pH}$ and $\mathrm{EC}$ were highest, and the values of SOM, SAN and SAP were lowest in NAR. The values of soil chemical properties in AGF were contrary to those in NAR (except soil EC). For other patterns, differences between soil $\mathrm{pH}$ in MES, CIS, SWR, ENP and ACS were not significant $(P>$ $0.05)$. The difference between soil EC in MES and ACS was not significant $(P>0.05)$. SOM in MES, SWR, ENP and ACS was similar $(P>0.05)$. There was no significant difference in SAN between CIS and AGF, or between MES, SWR and ENP $(P>0.05)$. Differences between SAP in SWR, ENP and ACS were not significant $(P>0.05)$.

\section{Variation in soil chemical properties and biochemical properties for different RRAF patterns}

The GLM showed that for type factors, only SAP, CAT and ACT significantly affected soil chemical properties and biochemical properties $(P<0.01)$. The pattern factor significantly affected soil chemical properties and biochemical properties apart from soil $\mathrm{pH}$ and CAT $(P>0.05$, Table 2). For most of the soil chemical properties and biochemical properties (13 out of a total of 15), the pattern factor significantly explained the total variation. In particular, variation was highest for the effect of pattern factor on TMA, which was up to 1670.86 .

Table 2. The sources of variation and its significance in soil chemical properties and microbial communities

\begin{tabular}{c|c|c|c|c|c}
\hline \multirow{2}{*}{ Microbial communities } & \multirow{2}{*}{ Type } & \multicolumn{2}{c}{ Source } \\
& Variable & Reclamation & $\begin{array}{c}\text { Ecological } \\
\text { restoration }\end{array}$ & Type \\
\cline { 2 - 5 } (within-type)
\end{tabular}

Asterisks indicate significant sources at $P<0.01(* *)$ and $P<0.001(* * *) ; n s$ not significant

\section{Soil enzyme activity}

For all patterns, all soil enzyme activity for NAR was at the lowest level; URE, SUC and PHO in AGF were the highest, and there was a significant difference in soil enzyme activity between AGF and NAR $(P<0.01$, Fig. 3). URE in CIS, ENP and NAR was 
similar $(P>0.05)$, and URE in SWR, ACS and AGF was similar $(P>0.05)$. The difference between SUC in MES and AGF was not significant $(P>0.05)$. The difference between CAT in SWR, ENP and ACS was not significant $(P>0.05)$, and CAT in SWR, ENP and ACS was significantly higher than for other patterns $(P<0.05$, Fig. 3).

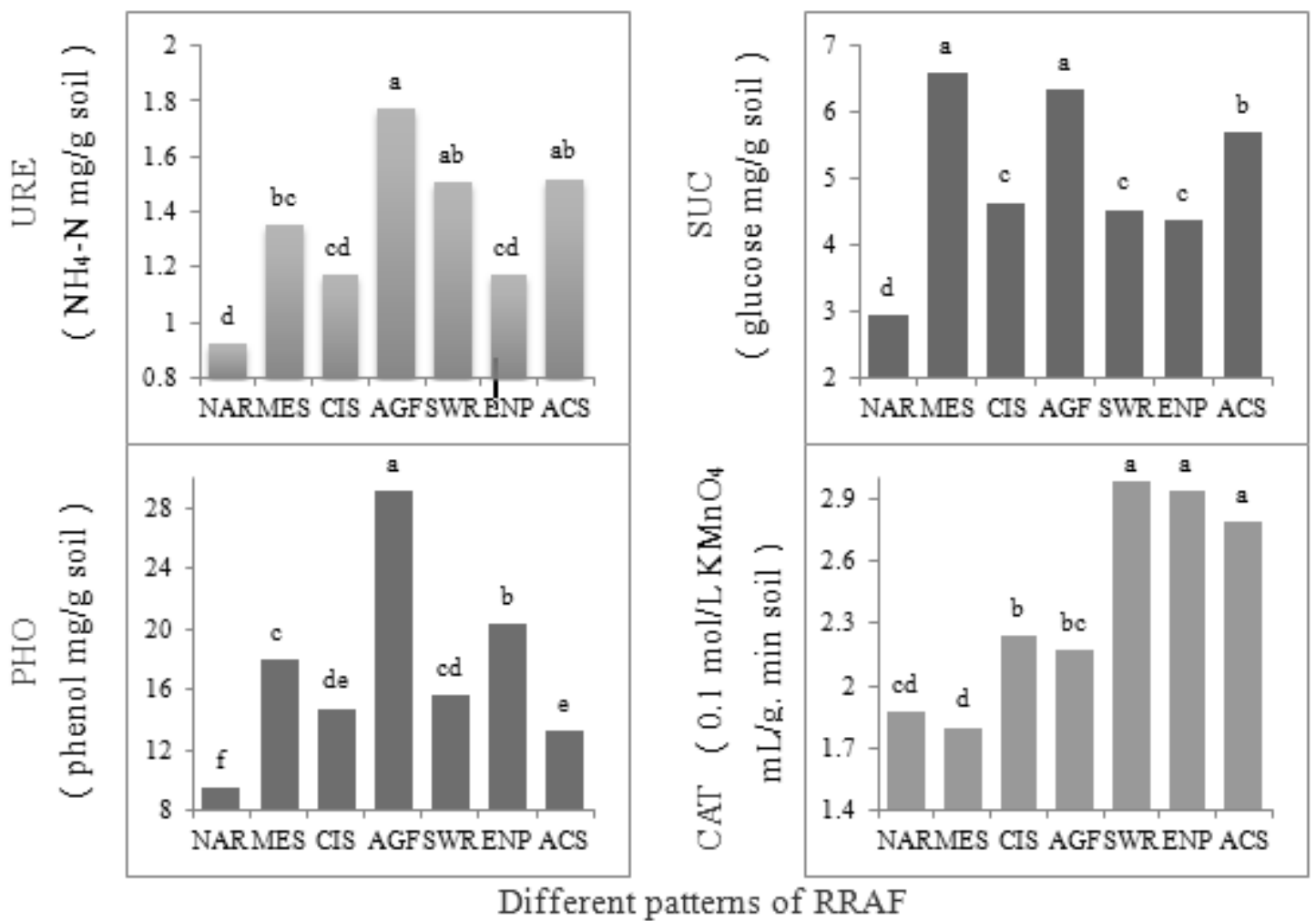

Figure 3. A comparison of four soil microbial enzyme activities

\section{Soil microbial communities}

Trends for soil microbial communities for different patterns were similar to those for soil enzyme activity: the values of soil microbial quantities and biomass in NAR were the lowest, while the values of soil microbial quantity and biomass in AGF were the highest. There was a significant difference between soil microbial communities in NAR and AGF $(P<0.01$, Fig. 4). For other patterns, MBC in CIS, SWR, ENP and NAR was similar $(P>0.05)$; MBC in MES, ACS and AGF was similar $(P>0.05)$. The difference between MBN in CIS, SWR, ENP and ACS was not significant $(P>0.05)$. There was no significant difference in BAC between SWR, ENP and ACS $(P>0.05)$. The difference between ACT in SWR, ENP and ACS was not significant $(P>0.05$, Fig. 4).

\section{PCA of soil microbial communities and enzyme activity}

Certain soil microbial communities and enzyme activity were well separated by pattern, according to soil chemical properties (Fig. 5A), and the classification of soil chemical properties for different patterns is shown in the PCA scatter plot (Fig. 5B): TMA, BAC and FUN were in accordance with the positive scores for PC1, and characterized the soil chemical properties of AGF; CAT was in agreement with the 
negative scores for PC1, and characterized the soil chemical properties of NAR. CAT, URE and MBC were in accordance with the positive scores for PC2, and characterized the soil chemical properties of ACS; ACT, TMA and MBN were in agreement with the negative scores for PC2, and characterized the soil chemical properties of NAR.

\section{Soil enzyme efficiency}

To indicate how RRAF pattern affects soil enzyme efficiency, soil enzyme activity was normalized, and expressed as enzyme activity per gram of soil MBC or MBN (URE normalized to $\mathrm{N}$, and SUC, PHO and CAT normalized to C). There were significant differences in soil enzyme efficiency between different patterns after the soil enzyme activity was normalized $(P<0.01$, Table 3$)$. When comparing normalized data with non-normalized data, no significant effects were found between enzyme activity in NAR, CIS, SWR and ENP. However, URE was significantly changed in AGF, URE now being the lowest in AGF when compared to other patterns (Table 3).

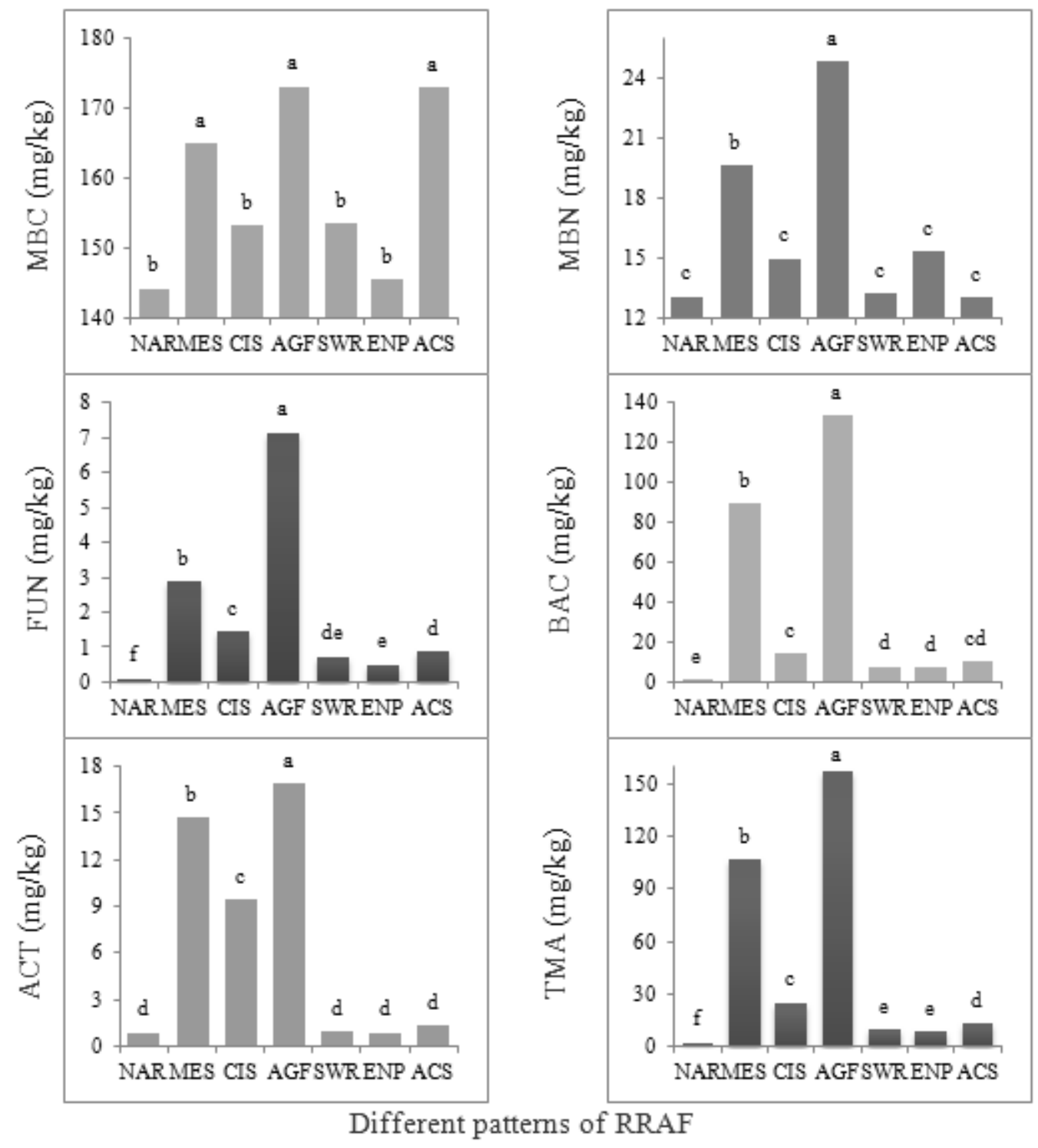

Figure 4. Soil microbial communities in different reclamation (ecological restoration) patterns 


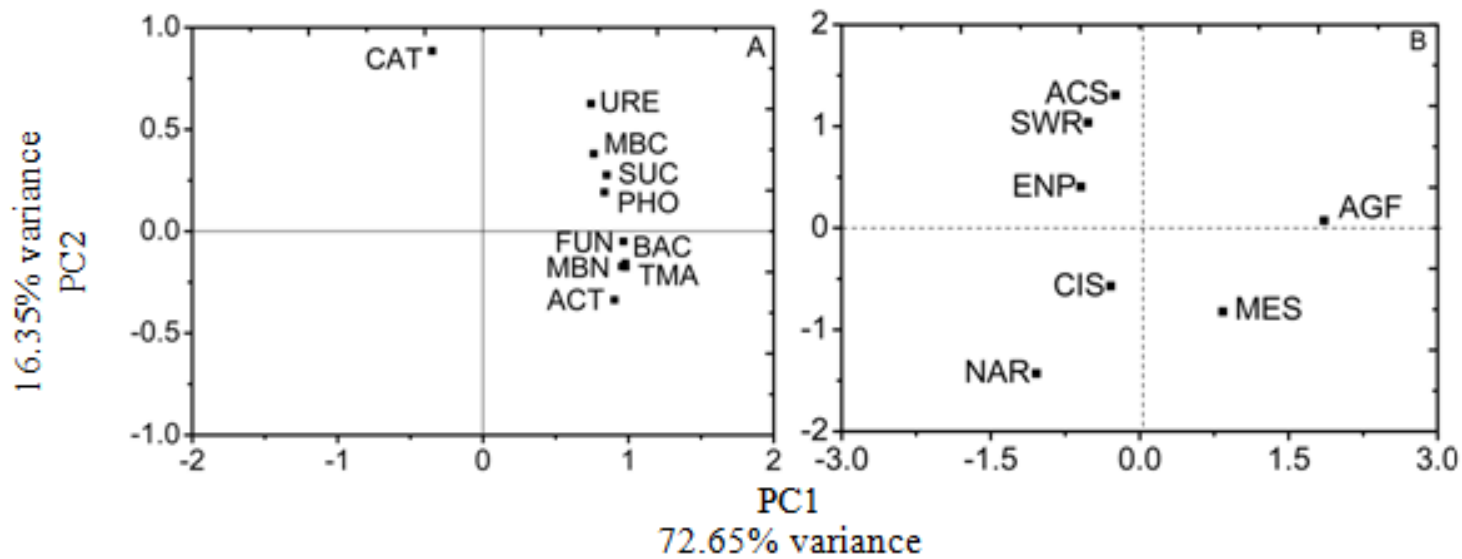

Figure 5. Principal component analysis (PCA) of the soil microbial communities and enzyme activities of different reclamation (ecological restoration) patterns from Shihezi of Xinjiang,

China. A Projection of soil microbial communities and enzyme activity variables onto the component plane. B Scatter plot of PC1-PC2 scores, each point represents a pattern of RRAF

Table 3. Soil microbial biomass $C$ and $N$ normalized values for soil enzyme activities in different reclamation (ecological restoration) pattern (mean $\pm S E$ )

\begin{tabular}{c|c|c|c|c|c|c|c}
\hline Type & Control & \multicolumn{3}{|c|}{ Reclamation } & \multicolumn{3}{c}{ Ecological restoration } \\
\hline Pattern & NAR & MES & CIS & AGF & SWR & ENP & ACS \\
\hline URE & $0.0703 \pm$ & $0.0688 \pm$ & $0.0781 \pm$ & $0.0712 \pm$ & $0.1139 \pm$ & $0.0762 \pm$ & $0.1165 \pm$ \\
$\left(\mathrm{NH}_{4}-\mathrm{N} \mathrm{mg} / \mathrm{g}\right.$ soil $)$ & $0.0020 \mathrm{~b}$ & $0.0024 \mathrm{~b}$ & $0.0053 \mathrm{~b}$ & $0.0054 \mathrm{~b}$ & $0.0047 \mathrm{a}$ & $0.0049 \mathrm{~b}$ & $0.0084 \mathrm{a}$ \\
\hline $\mathrm{SUC}$ & $0.0205 \pm$ & $0.0399 \pm$ & $0.0303 \pm$ & $0.0367 \pm$ & $0.0295 \pm$ & $0.0301 \pm$ & $0.0329 \pm$ \\
(glucose mg/g soil) & $0.0009 \mathrm{e}$ & $0.0010 \mathrm{a}$ & $0.0007 \mathrm{~d}$ & $0.0010 \mathrm{~b}$ & $0.0008 \mathrm{~d}$ & $0.0009 \mathrm{~d}$ & $0.0007 \mathrm{c}$ \\
\hline $\mathrm{PHO}$ & $0.0653 \pm$ & $0.1085 \pm$ & $0.0962 \pm$ & $0.1688 \pm$ & $0.1018 \pm$ & $0.1395 \pm$ & $0.0764 \pm$ \\
(phenol mg/g soil) & $0.0012 \mathrm{~d}$ & $0.0036 \mathrm{c}$ & $0.0037 \mathrm{c}$ & $0.0057 \mathrm{a}$ & $0.0039 \mathrm{c}$ & $0.0068 \mathrm{~b}$ & $0.0057 \mathrm{~d}$ \\
\hline $\mathrm{CAT}(0.1 \mathrm{~mol} / \mathrm{L} \mathrm{KMnO} 4$ & $0.0130 \pm$ & $0.0109 \pm$ & $0.0146 \pm$ & $0.0125 \pm$ & $0.0194 \pm$ & $0.0202 \pm$ & $0.0161 \pm$ \\
$\mathrm{mL} / \mathrm{g} . \mathrm{min} \mathrm{soil)}$ & $0.0004 \mathrm{~cd}$ & $0.0004 \mathrm{~d}$ & $0.0010 \mathrm{bc}$ & $0.0006 \mathrm{~cd}$ & $0.0008 \mathrm{a}$ & $0.0007 \mathrm{a}$ & $0.0006 \mathrm{~b}$ \\
\hline
\end{tabular}

Different letters indicate a significant difference among different patterns at $\mathrm{P}<0.01$ level

\section{Relationships between soil chemical properties and microbial variables}

Regression analysis between soil microbial variables showed the following significant relationships at $P<0.05$ level (Table 4): URE was positively related to SUC $(\mathrm{r}=0.772)$, URE was positively related to MBC $(\mathrm{r}=0.834)$, SUC was positively correlated with BAC $(\mathrm{r}=0.774)$, SUC was positively correlated with TMA $(\mathrm{r}=0.774)$, PHO was positively related to BAC $(\mathrm{r}=0.804)$, and PHO was positively related to TMA ( $\mathrm{r}=0.799)$. The following significant relationships were found at $P<0.01$ level (Table 4): SUC was positively related to MBC $(\mathrm{r}=0.878)$, PHO was positively related to MBN ( $\mathrm{r}=0.885)$, and PHO was positively correlated with FUN ( $\mathrm{r}=0.863)$. In particular, significant relationships at $P<0.01$ level were found between MBN, FUN, BAC, ACT and TMA (Table 4).

Regression analysis between soil chemical properties and microbial variables showed the following significant relationships (Table 4): $\mathrm{pH}$ was negatively correlated with URE ( $\mathrm{r}=-0.786)$, SUC $(\mathrm{r}=-0.951)$ and MBC $(\mathrm{r}=-0.935)$; SOM was positively related to URE $(r=0.822)$, PHO $(r=0.894)$, MBN $(r=0.806)$, FUN $(r=0.882)$, BAC 
$(\mathrm{r}=0.763)$ and TMA $(\mathrm{r}=0.769)$; SAP was positively correlated with MBN $(\mathrm{r}=0.777)$, FUN $(r=0.831)$, BAC $(r=0.753)$, ACT $(r=0.890)$ and TMA $(r=0.780)($ Table 4).

Table 4. Correlation matrix between soil chemical and microbial variables

\begin{tabular}{c|c|c|c|c|c|c|c|c|c}
\hline & URE & SUC & PHO & MBC & MBN & FUN & BAC & ACT & TMA \\
\hline pH & $\underline{-0.786}$ & $\mathbf{- 0 . 9 5 1}$ & -0.477 & $\mathbf{- 0 . 9 3 5}$ & -0.503 & -0.557 & -0.591 & -0.545 & -0.591 \\
SOM & $\underline{0.822}$ & 0.715 & $\mathbf{0 . 8 9 4}$ & 0.67 & $\underline{0.806}$ & $\mathbf{0 . 8 8 2}$ & $\underline{0.763}$ & 0.71 & $\underline{0.769}$ \\
SAP & 0.543 & 0.648 & 0.673 & 0.563 & $\underline{0.777}$ & $\underline{0.831}$ & $\underline{\underline{0.753}}$ & $\mathbf{0 . 8 9}$ & $\underline{0.78}$ \\
URE & & $\underline{0.772}$ & 0.685 & $\underline{0.834}$ & 0.579 & 0.706 & 0.635 & 0.454 & 0.624 \\
SUC & & & 0.625 & $\mathbf{0 . 8 7 8}$ & 0.699 & 0.701 & $\underline{0.774}$ & 0.734 & $\underline{0.774}$ \\
PHO & & & & 0.465 & $\mathbf{0 . 8 8 5}$ & $\mathbf{0 . 8 6 3}$ & $\underline{0.804}$ & 0.662 & $\underline{0.799}$ \\
MBN & & & & & & $\mathbf{0 . 9 6 3}$ & $\mathbf{0 . 9 7 6}$ & $\mathbf{0 . 8 9 7}$ & $\mathbf{0 . 9 7 7}$ \\
FUN & & & & & & & $\mathbf{0 . 9 5 6}$ & $\mathbf{0 . 8 6 6}$ & $\mathbf{0 . 9 5 7}$ \\
BAC & & & & & & & & $\mathbf{0 . 9 1 2}$ & $\mathbf{0 . 9 9 9}$ \\
ACT & & & & & & & & & $\mathbf{0 . 9 3 1}$ \\
\hline
\end{tabular}

Significant correlations shown in underlined $(\mathrm{P}<0.05)$ or in bold $(\mathrm{P}<0.01)$. Soil chemical and microbiological variables not included in the table were not significantly related other variables

\section{Discussion}

Soil chemical properties, microbial communities and enzyme activity were studied for different RRAF patterns in Shihezi, Xinjiang. For most soil parameters, more variation was explained by pattern than by type (Table 2), which shows that soil chemical properties, microbial communities and enzyme activity are significantly affected by pattern; significant differences between soil properties for different patterns also proved the result (Figs. 3 and 4).

The variation in soil microbial communities (BAC, FUN, ACT and TMA) was significant for different patterns, and the variation was especially high in TMA (Table 2), indicating that different patterns have a significant influence on microbial communities. BAC, FUN and ACT in soil are important in regulating ecological processes such as SOM decomposition, energy flow, carbon storage, etc. (Paul and Clark, 1997). FUN, BAC, ACT and TMA for each pattern were significantly higher than for NAR (except that ACT in SWR, ENP, ACS and NAR was similar); in particular, FUN, BAC, ACT and TMA in AGF were the highest (Fig. 4), which indicates that AGF has the strongest effect on soil microbial communities. It may be that the growth of microorganisms in AGF has been promoted by differences in litter quality and quantity, and root exudates (Monokrousos et al., 2006; Maestre et al., 2015). The values for SOM and SAP were lowest in NAR and were highest in AGF (Table 1); SOM was significantly related to FUN, BAC and TMA, and SAP was significantly related to FUN, BAC, ACT and TMA (Table 4). These correlations indicate that different patterns significantly influence microbial communities by improving SOM and SAP, and are in accordance with the report by Tan and Kang (2009). Significant relationships were found between FUN, BAC and ACT $(P<0.01$, Table 4), which indicates that microbial communities have the same response to changes in soil environment for different patterns. FUN, BAC and ACT showed significantly positive correlation with SAP, suggesting that SAP may be the dominant factor affecting the growth of microbial communities. 
Soil enzymes mainly come from microbial metabolic processes, soil animals and plant root exudates and residues (Bandick and Dick, 1999). In soil, enzyme activity is the foundation to ensure soil microbial quantity and soil physicochemical characteristics, which are closely connected to the cycles of $\mathrm{C}$ and $\mathrm{N}$ (Mersi and Schinner, 1991). As we expected, significant variation was found between soil enzyme activity for different patterns (Table 2). The soil enzyme activity for the six patterns was higher than for NAR (except for URE in CIS and ENP, and CAT in MES) (Fig. 3), showing the notable effects of different patterns on soil enzyme activity (Singh and Ghoshal, 2013; Nadimi-Goki et al., 2017). URE, SUC and PHO in AGF were the highest when compared to other patterns (Fig. 3), indicating that AGF can promote the utilization of $\mathrm{N}$, efficiency of the $\mathrm{C}$ cycle and the availability of soil $\mathrm{P}$ (Frankenberger and Johanson, 1983; Nannipieri et al., 2002).

Many studies have shown that soil enzyme activity is positively correlated with SOM (Bastida et al., 2012; Liu et al., 2013; Liang et al., 2014; Mahajan et al., 2016; Zhang et al., 2017), because SOM serves as a precursor for enzyme synthesis (Liu et al., 2013). Our research showed that SOM was positively correlated with URE and PHO ( $\mathrm{r}=0.822, P<0.05 ; \mathrm{r}=0.894, P<0.01$, respectively, Table 4). While soil $\mathrm{pH}$ was negatively related to URE and SUC (r $=-0.786, P<0.05 ; \mathrm{r}=-0.951, P<0.01$, respectively, Table 4), we did not find a significant relationship between soil EC and soil enzyme activity. These correlations indicate that the effect of soil $\mathrm{pH}$ on URE and SUC is greater than that of EC. This may be due to the tolerance of plants in different patterns to salt stress, and the high value of soil $\mathrm{pH}$ was the limiting factor for URE and SUC.

Generally, soil enzyme activity represents active members of microbial communities (Bradford et al., 2008). After soil enzyme activity was normalized by MBC or MBN, we could distinguish whether the microbial communities allocated energy to microbial growth or enzyme production (Schimel and Schaeffer, 2012). Intriguingly, when enzyme activity was normalized to MBC or MBN, MBN in AGF supported lower URE (Table 3), but was contrary to the data for non-normalized enzyme activity (Fig. 3). This shows a weak N cycle in AGF when compared with SWR and ACS. Namely, URE in AGF may respond more slowly to land use changes than the other two patterns. Changes in normalized URE in AGF also showed a change of physiological function in microbial communities: allocating more energy to microbial growth rather than to enzyme production (Bradford et al., 2008; Schimel and Schaeffer, 2012).

The PCA results indicated that PC1 of AGF, with a maximum positive score, characterized the highest values of both SOM and SAP, and was in agreement with the highest values of FUN, BAC and TMA. This indicates that higher values of SOM and SAP would mean higher soil microbial biomass (FUN, BAC and TMA). The soil properties in NAR were in contrast to those for AGF. Significant positive correlations between SOM and FUN, BAC and TMA, and between SAP and FUN, BAC and TMA also prove this result (Fig. 5; Table 4).

PC2 of ACS, with a maximum positive score, characterized the lowest value of soil $\mathrm{pH}$, which was in accordance with the highest URE and MBC, showing the high activity of soil enzymes. URE and MBC were lowest in NAR, indicating that the higher the $\mathrm{pH}$ value, the lower URE and $\mathrm{MBC}$, as also was proved by the negative relationship between soil pH and URE and MBC (Fig. 5; Table 4).

In addition, variations in most soil parameters were not significant between reclamation type and ecological restoration type (Table 2), which shows that there was 
no significant difference between the soil properties in different types, whether the reclamation type characterized the economic benefits or the ecological restoration characterized the ecological benefits. There was a significant difference between characteristics of soil chemistry and biochemical properties were observed for different patterns. The higher the values of SOM and SAP, the greater the values of MBN, FUN, $\mathrm{BAC}$ and TMA, and the higher the value of soil $\mathrm{pH}$ in accordance with lower values of URE, SUC and MBC in soil. These correlations indicate that different plant composition, soil biochemical characteristics and human activities in different patterns have significant influences on soil biochemical properties (Lal, 2005; Singh and Ghoshal, 2013).

\section{Conclusions}

In this paper, changes in soil chemical and biochemical properties with different patterns were studied. In terms of improving soil quality, it is meaningful to use both the reclamation type and ecological restoration type in abandoned farmlands. Most soil chemical and microbial characteristics for AGF were significantly higher than for other patterns and NAR (Table 1; Figs. 3 and 4), demonstrating the obvious effects of AGF on soil fertility improvement (Tian et al., 2013). AGF could be used as the preferred reclamation pattern for abandoned farmland in salinized regions, because it accounts for the vulnerability of the ecological environment (arid, low temperature and salinization stress) in the sample area, as well as having both economic and ecological benefits. It should be noted that SWR could be a good choice during the early stage of RRAF, by increasing the soil water content (data not shown), and improving soil quality (particularly in soil EC, SOM, SAN, URE, SUC, PHO, CAT, FUN, BAC and TMA) when compared to NAR, thus promoting the establishment of vegetation. All patterns in our experiment have certain effects on improving the quality of soil, and this will provide references for RRAF in drought and salinized regions.

Although an optimal RRAF pattern can be selected by comparing soil chemical and biochemical properties, however, further study is needed to focus on the hydrological cycle to ensure the sustainable utilization of water resources in arid regions. Moreover, the long-term dynamic study also needed for more objective evaluation on RRAF.

Acknowledgements. This study was funded by the National Key Research and Development Program of China (2016YFC0501406), and by the Science and Technology Development \& Achievements Transformation of Xinjiang Production and Construction Corps (2016AD022).

\section{REFERENCES}

[1] Bandick, A. K., Dick, R. P. (1999): Field management effects on soil enzyme activities. Soil Biol. Biochem. 31: 1471-1479.

[2] Bastida, F., Zsolnay, A., Hernández, T., García, C. (2008): Past, present and future of soil quality indices: a biological perspective. - Geoderma 147: 159-171.

[3] Bastida, F., Jindo, K., Moreno, J. L., Hernàndez, T., Carlos, G. (2012): Effect of organic amendments on soil carbon fractions, enzyme activity and humus-enzyme complexes under semi-arid conditions. - Eur. J. Soil Biol. 53: 94-102. 
[4] Bonet, A. (2004): Secondary succession of semi-arid Mediterranean old-fields in southeastern Spain: insights for conservation and restoration of degraded lands. - J. Arid. Environ. 56: 213-233.

[5] Bradford, M. A., Davies, C. A., Frey, S. D., Maddox, T. R., Melillo, J. M., Mohan, J. E., Reynolds, J. F., Treseder, K. K., Wallenstein, M. D. (2008): Thermal adaptation of soil microbial respiration to elevated temperature. - Ecol. Lett. 11: 1316-1327.

[6] Brookes, P. C., Landman, A., Pruden, G., Jenkinson, D. S. (1985): Chloroform fumigation and the release of soil nitrogen: a rapid direct extraction method to measure microbial biomass nitrogen in soil. - Soil Biol. Biochem. 17: 837-842.

[7] Bulluck, L. R., Brosius, M., Evanylo, G. K., Ristaino, J. B. (2002): Organic and synthetic fertility amendments influence soil microbial, physical and chemical properties on organic and conventional farms. - Appl. Soil Ecol. 19: 147-160.

[8] Castellanos, A. E., Martinez, M. J., Llano, J. M., Halvorson, W. L., Espiricueta, M., Espejel, I. (2005): Successional trends in Sonoran Desert abandoned agricultural fields in northern Mexico. - J. Arid Environ. 60: 437-455.

[9] Degens, B. P., Schippers, L. A., Sparling, G. P., Vojvodic-Vukovic, M. (2000): Decreases in inorganic $\mathrm{C}$ reserves in soils can reduce the catabolic diversity of soil microbial communities. - Soil Biol. Biochem. 32: 189-196.

[10] Fan, H., Pan, X., Li, Y., Chen, F., Zhang, F. (2008): Evaluation of soil environment after saline soil reclamation of Xinjiang Oasis, China. - Agron. J. 100: 471-476.

[11] Feng, Y. X., Luo, G. P., Lu, L., Zhou, D. C., Han, Q. F., Xu, W. Q., Yin, C. Y., Zhu, L., Dai, L., Li, Y. Z., Li, C. F. (2011): Sustainable agricultural paradigm of mountain-oasisecotone-desert system in inland Manasi river basin, Xinjiang province, northwest China. - Environ. Earth Sci. 64: 2067-2077.

[12] Frankenberger Jr, W. T., Johanson, J. B. (1983): Factors affecting invertase activity in soils. - Plant Soil 74: 313-323.

[13] GLP (2005): Science Plan and Implementation Strategy. IGBP Report No. 53/IHDP Report 19. - IGBP Secretariat, Stockholm, Sweden.

[14] Guan, S. Y. (1986): Soil Enzyme and Its Research Methods. - China Agriculture Press, Beijing (in Chinese).

[15] Guo, X. M., Ma, T., Chen, L. Z., Cui, Y. H., Du, P., Liao, Y. (2014): Microbial quantities and enzyme activity in soil irrigated with sewage for different lengths of time. Ecotoxicology 23: 2062-2068.

[16] Keeney, D. R., Nelson, D. W. (1982): Nitrogen-Inorganic Forms. In: Page, A. L., Miller, R. H., Keeney, D. R. (eds.) Methods of Soil Analysis. - American Society of Agronomy, Madison, WI.

[17] Lal, R. (2005): World crop residues production and implications of its use as a biofuel. Environ. Int. 31: 575-584.

[18] Li, J. J., Zheng, Y. M., Yan, J. X., Li, H. J., He, J. Z. (2013): Succession of plant and soil microbial communities with restoration of abandoned land in the Loess Plateau, China. J. Soil. Sediment. 13: 760-769.

[19] Li, Y. L., Qao, M., Yang, X. L., Zhou, S. B., Zeng, Y. J. (2008): Analysis on land use/cover change and landscape fragmentation in typical watershed of arid zone in last 30 years-a case of Manasi river watershed, Xinjiang. - J. Desert Res. 28: 1050-1057 (in Chinese).

[20] Liang, Q., Haiqing, C., Gong, Y., Yang, H., Fan, M., Kuzyakov, Y. (2014): Effects of 15 years of manure and mineral fertilizers on enzyme activities in particle-size fractions in a North China plain soil. - Eur. J. Soil Biol. 60: 112-119.

[21] Liu, C., Xu, J. M., Ding, N. F., Fu, Q. L., Guo, B., Lin, Y. C., Li, H., Li, N. Y. (2013): The effect of long-term reclamation on enzyme activities and microbial community structure of saline soil at Shangyu, China. - Environ. Earth Sci. 69: 151-159. 
[22] Luo, G. P., Chen, X., Zhou, K. F., Ye, M. Q. (2003): Temporal and spatial variation and the stability of the oasis in the Sangong River Watershed, Xinjiang, China. - Sci. China (Series D) 46: 62-72.

[23] Maestre, F. T., Delgado-Baquerizo, M., Jeffries, T. C., Eldridge, D. J., Ochoa, V., Gozalo, B., Quero, J. L., García-Gómez, M., Gallardo, A., Ulrich, W., Bowker, M. A., Arredondo, T., Barraza-Zepeda, C., Bran, D., Florentino, A., Gaitán, J., Gutiérrez, J. R., Huber-Sannwald, E., Jankju, M., Mau, R. L., Miriti, M., Naseri, K., Ospina, A., Stavi, I., Wang, D., Woods, N. N., Yan, X., Zaady, E., Singh, B. K. (2015): Increasing aridity reduces soil microbial diversity and abundance in global drylands. - P. Natl. Acad. Sci. USA 112: $15684-15689$.

[24] Mahajan, G. R., Manjunath, B. L., Latare, A. M., D’Souza, R., Vishwakarma, S., Singh, N. P. (2016): Microbial and enzyme activities and carbon stock in unique coastal acid saline soils of Goa. - P. Natl. A. Sci. India B Biol. Sci. 86: 961-971.

[25] McCullagh, P., Nelder, J. A. (1989): Generalized Linear Models. 2nd Ed. - Chapman \& Hall, London.

[26] Mersi, W., Schinner, F. (1991): An improved and accurate method for determining the dehydrogenase activity of soils with iodonitrotetrazolium chloride. - Biol. Fert. Soils 11: 216-220.

[27] Monokrousos, N., Papatheodorou, E. M., Diamantopoulos, J. D., Stamou, G. P. (2006): Soil quality variables in organically and conventionally cultivated field sites. - Soil Biol. Biochem. 38: 1282-1289.

[28] Nadimi-Goki, M., Bini, C., Wahsha, M., Kato, Y., Fornasier, F. (2017): Enzyme dynamics in contaminated paddy soils under different cropping patterns (NE Italy). - J. Soil. Sediment. DOI: 10.1007/s11368-017-1830-1.

[29] Nannipieri, P., Kandeler, E., Ruggiero, P. (2002): Enzyme Activities and Microbiological and Biochemical Processes in Soil. In: Burns, R. G., Dick, R. P. (eds.) Enzymes in the Environment: Activity Ecology and Applications. - Marcel Dekker, New York.

[30] Nannipieri, P., Ascher, J., Ceccherini, M. T., Landi, L., Pietramellara, G., Renella, G. (2003): Microbial diversity and soil function. - Eur. J. Soil. Sci. 54: 665-670.

[31] Patra, A. K., Abbadie, L., Clays-Josserand, A., Degrange, V., Grayston, S. J., Loiseau, P., Loualt, F., Mahmood, S., Nazaret, S., Philippot, L., Poly, F., Prosser, J. I., Richaume, A., Le Roux, X. (2005): Effects of grazing on microbial functional groups involved in soil N dynamics. - Ecol. Monogr. 75: 65-80.

[32] Paul, E. A., Clark, F. E. (1997): Soil Microbiology and Biochemistry. - Academic Press, San Diego, CA.

[33] Qian, Y. B., Fan, Z. L., Lei, J. Q., Wu, Z. N. (2006): Exploitation of water and land resources and its ecoenvironment issues in Xinjiang of China in resent 50 a. - J. Arid Land Resour. Environ. 20: 58-63 (in Chinese).

[34] Raiesi, F., Beheshti, A. (2014): Soil C turnover, microbial biomass and respiration, and enzymatic activities following rangeland conversion to wheat-alfalfa cropping in a semiarid climate. - Environ. Earth Sci. 72: 5073-5088.

[35] Rasapoor, M., Nasrabadi, T., Kamali, M., Hoveidi, H. (2009): The effects of aeration rate on generated compost quality, using aerated static pile method. - Waste Manag. 29: 570573.

[36] Romo-Leon, J. R., van Leeuwen, W. J. D., Castellanos-Villegas, A. (2016): Land use and environmental variability impacts on the phenology of arid agro-ecosystems. - Environ. Manage. 57: 283-297.

[37] Schimel, J. P., Schaeffer, S. M. (2012): Microbial control over carbon cycling in soil. Front Microbiol. 3: 348.

[38] Singh, A., Ghoshal, N. (2013): Impact of herbicide and various soil amendments on soil enzymes activities in a tropical rainfed agroecosystem. - Eur. J. Soil Biol. 54: 56-62. 
[39] Stott, D. E., Andrews, S. S., Leibig, M. A., Weinhold, B. J., Karlen, D. L. (2010): Evaluation of $\beta$-glucosidase activity as a soil quality indicator for the soil management assessment framework. - Soil Biol. Biochem. 74: 107-119.

[40] Suding, K. N. (2011): Toward an era of restoration in ecology: success, failures, and opportunities ahead. - Annu. Rev. Ecol. Evol. S. 42: 465-487.

[41] Tan, J. L., Kang, Y. H. (2009): Changes in soil properties under the influences of cropping and drip irrigation during the reclamation of severe salt-affected soils. - Agric. Sci. China 8: 1228-1237.

[42] Tian, Y. L., Cao, F. L., Wang, G. B. (2013): Soil microbiological properties and enzyme activity in Ginkgo-tea agroforestry compared with monoculture. - Agroforest Syst. 87: 1201-1210.

[43] UN General Assembly. (1997): Elaboration of an International Convention to Combat Desertification in Countries Experiencing Serious Drought and/or Desertification and Particular in Africa. Final Negotiations Text of the Convention. - UN General Assembly, Geneva.

[44] Vance, E., Brookes, P., Jenkinson, D. (1987): An extraction method for measuring soil microbial biomass C. - Soil Biol. Biochem. 19: 703-707.

[45] Xue, D., Yao, H. Y., Ge, D. Y., Huang, C. Y. (2008): Soil microbial structure in diverse land use systems: a comparative study using Biolog, DGGE, and PLFA analyses. Pedosphere 18: 653-663.

[46] Yang, H. C., Zhang, F. H., Chen, Y., Xu, T. B., Cheng, Z. B., Liang, J. (2016): Assessment of reclamation treatments of abandoned farmland in an arid region of China. - Sustainability 8: 1183. DOI: 10.3390/su8111183.

[47] Yin, J. Y., Zhang, L. M., Wei, W. X., He, J. Z. (2013): Effects of land utilization patterns on soil microbial communities in an acid red soil based on DNA and PLFA analyses. - J. Soil. Sediment. 13: 1223-1231.

[48] Zhang, Q., Li, Z. W., Huang, B., Luo, N. L., Long, L. Z., Huang, M., Zhai, X. Q., Zeng, G. M. (2017): Effect of land use pattern change from paddy soil to vegetable soil on the adsorption-desorption of cadmium by soil aggregates. - Environ Sci. Pollut. Res. 24: 2734-2743.

[49] Zhou, J., Zhang, F. R., Xu, Y., Gao, Y., Xie, Z. (2017): Evaluation of land reclamation and implications of ecological restoration for agro-pastoral ecotone: case study of Horqin Left Back Banner in China. - Chin. Geogra. Sci. 27: 772-783.

[50] Zhou, X. G., Yu, G. B., Wu, F. Z. (2011): Effects of intercropping cucumber with onion or garlic on soil enzyme activities, microbial communities and cucumber yield. - Eur. J. Soil Biol. 47: 279-287. 